\title{
The Prevalence of tet(A) and tet(M) Tetracycline Resistance Genes in Municipal Wastewater
}

\author{
Jakub Hubeny', Martyna Buta', Wiktor Zieliński', Monika Harnisz', \\ Ewa Korzeniewska', Monika Nowrotek², Grażyna Płaza²
}

1 Department of Environmental Microbiology, University of Warmia and Mazury, ul. Prawocheńskiego 1, 10-720, Olsztyn, Poland

2 Department of Environmental Microbiology, Institute for Ecology of Industrial Areas, ul. Kossutha 6, 40-844 Katowice, Poland

* Corresponding author's e-mail: jakub.hubeny@uwm.edu.pl

\begin{abstract}
Antibiotic resistance is a widespread problem that poses one of the greatest risks to public health around the world. The main cause of antibiotic resistance is the overuse of antibiotics in the human and veterinary medicine and in agriculture. Drugs are released into the environment with treated wastewater, and they can act as stressors that increase the prevalence of antibiotic resistance genes (ARGs). Wastewater treatment plants (WWTPs) are not equipped with appropriate technologies for eliminating the genetic material from the treated wastewater. In this study, the prevalence of tet(A) and tet(M) genes encoding resistance to tetracycline antibiotics was investigated in the samples of municipal wastewater and sewage sludge collected from two WWTPs and in the water samples collected from rivers which receive the treated wastewater. The samples were collected in two seasons of the year (summer and fall). The presence of ARGs was confirmed by PCR. The study revealed that ARGs were not effectively removed from wastewater by the WWTP in the Region of Silesia. Seasonal variations in the occurrence of the analyzed genes were not observed in the samples collected from the above-mentioned plant. Tetracycline resistance genes were detected in all samples of river water. The tet(A) gene was not removed from the treated wastewater in the WWTP in the Region of Warmia and Mazury, whereas the tet(M) gene was detected on a seasonal basis. The tet $(\mathrm{M})$ gene was not detected in the samples of river water collected upstream and downstream from the WWTP. The study demonstrated that the existing WWTPs lack the means to eliminate ARGs. The wastewater treatment systems have to be modified to effectively remove ARGs from the treated wastewater.
\end{abstract}

Keywords: WWTPs, tetracycline, ARGs, ARB, antibiotic resistance, environment, wastewater

\section{INTRODUCTION}

The antibiotic resistance is a widespread problem that poses one of the greatest risks to public health around the world. The main cause of antibiotic resistance is the overuse of antibiotics in the human and veterinary medicine and in agriculture [Kümmerer, 2009]. Massive amounts (tons) of antibiotics have been discharged into the natural environment since the discovery of penicillin in 1928 [Harnisz et al., 2015]. Antibiotics are partially or completely metabolized by humans and animals. These parent compounds and their transformation products, pharmacologically active or inactive, are excreted from the body with urine and feces, and are discharged with wastewater to wastewater treatment plants (WWTPs). The antibiotic concentrations are partially reduced during the wastewater treatment, but residual drugs are discharged to the environment with the treated effluents [Reijnders et al., 2016]. Livestock production is yet another source of the antibiotic contamination. Antibiotics are frequently overused in animal farms, and are excreted with feces. Manure contaminated with antibiotics can promote the transfer of active metabolites from the soil surface to surface and ground water $[\mathrm{He}$ et al., 2016]. According to the surveillance reported 
published by the World Health Organization in 2014, the antibiotic resistance poses a problem so serious that it threatens the achievements of modern medicine [WHO, 2014]. The antibiotic pollution continues to increase in excess of environmental safety thresholds, which contributes to the spread of antibiotic resistance.

Horizontal gene transfer (HGT) is the main mechanism responsible for the lateral exchange of the genetic material between organisms. This mechanism was first described in 1940 [Soucy et al., 2015]. Horizontal gene transfer supports the emergence of new traits that are helpful for survival. The first rule of HGT states that the transferred genetic material should not harm the recipient [Park \& Zhang, 2012]. This mechanism has been long recognized as one of the key driving forces in the evolution of bacteria and archaea [Boto, 2014]. Horizontal gene transfer has been extensively researched as the main mechanism supporting the exchange of antibiotic resistance genes. The resistance to antibiotics can also be conferred by mutations [von Wintersdorff et al., 2016].

The antibiotic resistance genes (ARGs) are responsible for the present pandemic of antimicrobial resistance around the world. Environmental bacteria have been found to promote the development of antibiotic resistance in clinical strains [Xiong et al., 2015]. Human pathogens can also acquire ARGs in the natural environment. The transfer of ARGs produces the diseases that are increasingly difficult to treat [D'Costa et al., 2011]. Animal, human and plant pathogens as well as bacteria colonizing different habitats share a common pool of ARGs [Schlüter et al., 2007].

Tetracyclines are among the most frequently prescribed antibiotics in the world [Jeong et al., 2010]. They are widely used in the human and veterinary medicine and in agriculture. Tetracyclines are not completely metabolized, and more than $70 \%$ of the ingested antibiotics are excreted with urine and feces as active metabolites [Daghrir \& Drogui, 2013]. Due to their overuse and strong adsorption properties, tetracyclines are ubiquitous in soil and aquatic environments. The presence of tetracycline and tetracycline resistance genes has been reported from surface water bodies, wastewater, soil and sewage sludge [ $\mathrm{Li}$ et al., 2011, Chen et al., 2011]. In 2011, Deblonde et al. demonstrated that WWTPs do not effectively remove tetracyclines and genes encoding resistance to these antibiotics. Wastewater treatment plants lack the appropriate technology for eliminating the genetic material from processed sewage [Laht et al., 2014].

The aim of this study was to determine the prevalence of tet( $(\mathrm{A})$ and tet $(\mathrm{M})$ tetracycline resistance genes in the samples of wastewater and sewage sludge collected from a WWTP in the Region of Silesia and one WWTP in the Region of Warmia and Mazury. The presence of the same tetracycline resistance genes was also analyzed in the rivers that act as recipients of the treated effluents. The samples of river water were collected in summer and fall to determine the seasonal variations in the prevalence of the examined genes. The presence of ARGs was monitored at every stage of the treatment process to evaluate the efficiency of their removal in the studied WWTPs.

\section{MATERIALS AND METHODS}

\section{Research site}

The wastewater samples were collected for analysis from two WWTPs in the Region of Silesia (S-WWTP) and the Region of Warmia and Mazury (WM-WWTP). WM-WWTP processes municipal wastewater (estimated population of $175,000)$ and wastewater from three hospitals [Korzeniewska and Harnisz, 2013]. The purification process involves preliminary treatment, (screening and grit removal), primary treatment (gravity sedimentation tanks), and secondary treatment (activated sludge with deep aeration). The plant has an average processing capacity of $35000 \mathrm{~m}^{3} / \mathrm{d}$ [Harnisz and Korzeniewska, 2018]. In S-WWTP, wastewater undergoes mechanical and biological treatment with supplementary chemical processing for phosphorus removal. The plant has an average processing capacity of $33,000 \mathrm{~m}^{3} / \mathrm{d}$ [http://www.rcgw.pl].

\section{Sample collection}

The samples were collected twice, in June and November 2018. The wastewater and sewage sludge were sampled during selected stages of the treatment process in both WWTPs. The water samples were collected from the rivers that receive treated effluents. The location of sampling sites is presented in Table 1. The wastewater and river water were sampled into sterile $500 \mathrm{ml}$ bottles (SIMAX), and sludge was sampled into sterile $50 \mathrm{ml}$ conical tubes. The collected samples 
were transported to the laboratory and stored at $4^{\circ} \mathrm{C}$ until analysis.

\section{DNA extraction}

The samples of sewage and river water were filtered with a vacuum pump (MilliPore, Merck) with polycarbonate membrane filters with $0.2 \mu \mathrm{m}$ porosity and a diameter of $47 \mathrm{~mm}$. The volume of the filtered samples is presented in Table 2. The sludge samples were not filtered and were used directly for DNA isolation.

Genomic DNA was isolated from the wastewater and river water with the DNeasy Power Water Kit (Qiagen), and from the sewage sludge with the DNeasy Power Soil Kit (Qiagen) in accordance with the manufacturer's recommendations.

\section{PCR assay}

The presence of tetracycline resistance genes in the collected samples was determined in a PCR assay. The reaction mix had a total volume of $20 \mu \mathrm{l}$, and it was composed of: NZYTaq II $2 \mathrm{xGreen}$ Master Mix, $10 \mu \mathrm{M}$ of respective primer pairs [Table 3], and $1 \mu \mathrm{l}$ of template DNA. The PCR products were separated electrophoretically in $1.5 \%$ agarose gel with the addition of ethidium bromide $(1 \mu \mathrm{g} / \mathrm{mL})$. Electrophoretic separation was conducted at $120 \mathrm{~V}$ for 5 minutes, and then at $100 \mathrm{~V}$ for 60 minutes in $1 \mathrm{x}$ TBE buffer.

\section{RESULTS AND DISCUSSION}

Wastewater treatment plants process sewage from various sources, including households, hospitals and pharmaceutical companies. These types of wastewater contain antibiotics, antibiotic-resistant bacteria (ARB) and ARGs [Michael et al., 2013]. Liquid wastes, containing billions of bacterial cells and high concentrations of nutrients, act as evolutionary incubators. The presence of the drug resistance genes in effluents can contribute to the exchange of the genetic material via HGT [Gao et al., 2012]. As a result, WWTPs are potential hotspots for the exchange of ARGs [Moura et al., 2010].

The evaluated WWTPs operate similar treatment systems and have similar processing capacity. The tet(A) gene was detected in all wastewater samples from both WWTPs and in the water samples collected from both rivers. The tet(A) gene was present in the samples collected in both analyzed seasons. The tet(M) gene was identified in all samples from S-WWTP, whereas its prevalence in the samples from WM-WWTP was reduced (the tet $(\mathrm{M})$ gene was not detected in the samples of treated wastewater collected in November 2018). The tet(M) gene was not identified in the samples of river water collected downstream from WM-WWTP in both seasons [Tables 4 and 5].

The presence and stable prevalence of the tet(A) gene in all samples collected from both WWTPs could be attributed to its high abundance in the environment and raw sewage $[\mathrm{Xu}$ et al., 2013]. In contrast, the $\operatorname{tet}(\mathrm{M})$ gene was not identified in the treated wastewater in WMWWTP or in the samples of river water collected downstream from WM-WWTP. Chen and Zheng [2013] detected the tetracycline resistance genes in all stages of mechanical and biological sewage treatment. In their study, the concentration

Table 1. Sampling sites

\begin{tabular}{|c|l|c|l|}
\hline \multicolumn{2}{|c|}{$\begin{array}{c}\text { Mastewater treatment plant in the Region of Warmia and } \\
\text { Mazury }\end{array}$} & \multicolumn{1}{|c|}{ Sample } & Symbol \\
\hline Symbol & \multicolumn{1}{|c|}{ Sastewater treatment plant in the Region of Silesia } \\
\hline P1 & Raw sewage & P1 & Raw sewage \\
\hline P2 & Sewage after primary sedimentation & P2 & Sewage after primary sedimentation \\
\hline P3 & Sewage treated in a biological reactor & P3 & Sewage after secondary sedimentation \\
\hline P4 & Sewage treated in a multipurpose reactor & P4 & Sewage treated in a C-TECH reactor \\
\hline P5 & Treated wastewater & P5 & Treated wastewater \\
\hline P6 & $\begin{array}{l}\text { River water - upstream from the effluent discharge } \\
\text { point }\end{array}$ & P6 & $\begin{array}{l}\text { River water - upstream from the effluent discharge } \\
\text { point }\end{array}$ \\
\hline P7 & $\begin{array}{l}\text { River water - downstream from the effluent } \\
\text { discharge point }\end{array}$ & P7 & $\begin{array}{l}\text { River water - downstream from the effluent } \\
\text { discharge point }\end{array}$ \\
\hline P8 & Sludge from the open fermentation tank & P8 & Dewatered sludge \\
\hline P9 & Dewatered sludge & P9 & Mechanically compacted sludge \\
\hline & & P10 & Sludge after gravity thickening \\
\hline
\end{tabular}


Table 2. Volume of filtered river water and wastewater samples

\begin{tabular}{|c|c|c|}
\hline \multirow{2}{*}{ Symbol } & \multicolumn{2}{|c|}{ Filtered volume [ml] } \\
\cline { 2 - 3 } & June & November \\
\hline P1 & 40 & 40 \\
\hline P2 & 40 & 40 \\
\hline P3 & 20 & 20 \\
\hline P4 & 40 & 40 \\
\hline P5 & 200 & 200 \\
\hline P6 & 400 & 400 \\
\hline P7 & 400 & 400 \\
\hline P1 & 10 & 40 \\
\hline P2 & 30 & 30 \\
\hline P3 & 200 & 300 \\
\hline P4 & 200 & 300 \\
\hline P5 & 150 & 300 \\
\hline P6 & 150 & 300 \\
\hline P7 & 150 & 300 \\
\hline P8 & 10 & 30 \\
\hline
\end{tabular}

of the tet $(\mathrm{M})$ gene was reduced by three orders of magnitude after wastewater treatment, relative to the $\operatorname{tet}(\mathrm{A})$ gene. Similar results were reported by Zhang and Zhang [2011] who analyzed the prevalence of 14 tetracycline resistance genes in 15 WWTPs in China. The cited study demonstrated that six genes $(\operatorname{tet}(\mathrm{A}), \operatorname{tet}(\mathrm{C}), \operatorname{tet}(\mathrm{G})$, $\operatorname{tet}(\mathrm{M}), \operatorname{tet}(\mathrm{S})$ and $\operatorname{tet}(\mathrm{X}))$ were continuously present in the samples collected from all WWTPs, and quantitative PCR revealed that $\operatorname{tet}(\mathrm{A})$ was the most prevalent tetracycline resistance gene [Zhang and Zhang, 2011].

In the present study, the absence of the $\operatorname{tet}(\mathrm{M})$ gene in the samples of river water collected upstream from WM-WWTP could point to low concentrations of this gene in the environment. In turn, the absence of the tet $(\mathrm{M})$ gene in the samples of river water collected downstream from WM-WWTP could result from the dilution of discharged effluents and very low concentrations of the $\operatorname{tet}(\mathrm{M})$ gene that were below the detection limit [Kümmerer, 2009]. The presence of both analyzed genes in all samples from S-WWTP could indicate that the tetracycline resistance genes are far more prevalent in Silesia than in Warmia and Mazury. Tetracyclines are widely used in medicine and livestock production, and the genes encoding resistance to this class of antibiotics are encountered in various environments. In soil, the most prevalent tetracycline resistance genes are $t e t(\mathrm{~W}), \operatorname{tet}(\mathrm{X}), \operatorname{tet}(\mathrm{L}), \operatorname{tet}(\mathrm{M})$ and $\operatorname{tet}(\mathrm{G})[\mathrm{Ghosh}$ and LaPara, 2007]. Zhu et al. [2013] reported the highest concentrations of $\operatorname{tet}(\mathrm{W}), \operatorname{tet}(\mathrm{X}), \operatorname{tet}(\mathrm{L})$, $\operatorname{tet}(\mathrm{M})$ and $\operatorname{tet}(\mathrm{G})$ in manure, and the highest prevalence of $\operatorname{tet}(\mathrm{L}), \operatorname{tet}(\mathrm{A})$ and $\operatorname{tet}(\mathrm{M})$ in soil fertilized with manure. $\operatorname{tet}(\mathrm{A})$ and $\operatorname{tet}(\mathrm{M})$ is exhibited by a wide range of host species, including the microorganisms of the Aeromonas, Escherichia, Bacillus, Pseudomonas and Vibrio genera. According to Zhang et al. [2009], tet(A) and tet(M) are most frequently encountered in activated sludge, treated effluents, potable water and surface water. In the current study, these genes were detected in all stages of wastewater treatment in both WWTPs, which suggests that WWTPs could act as hotspots for the accumulation and exchange of genetic elements that confer the antibiotic resistance [Guo et al., 2017]. Wastewater treatment plants process various types of sewage which contain a broad range of ARGs [Zhang and Li, 2011]. It contributes to the creation of ecological niches with high concentrations of biomass and HGT inductors, which facilitates the replication and exchange of genetic material [Rizzo et al., 2013].

\section{CONCLUSIONS}

Imperfect wastewater treatment systems in WWTPs and the discharge of treated effluents to rivers contribute to the spread of ARGs in the environment. This study revealed a high prevalence of the tetracycline resistance genes in environmental samples, which confirms the observation that WWTPs are potential point sources of resistance genes. Bacterial cells are accumulated during wastewater treatment, and they can interact with ARGs to create multidrug-resistant strains. The study demonstrated that genetic elements are

Table 3. Primer sequences

\begin{tabular}{|c|c|c|c|c|c|}
\hline \multicolumn{2}{|c|}{ Primer } & $3^{\prime} \rightarrow 5^{\prime}$ primer sequence & $\begin{array}{c}\text { Size of amplification } \\
\text { product (bp) }\end{array}$ & Source & $\begin{array}{c}\text { Annealing } \\
\text { temperature }\left({ }^{\circ} \mathrm{C}\right)\end{array}$ \\
\hline \multirow{2}{*}{$\operatorname{tet}(\mathrm{A})$} & $\mathrm{F}$ & GCTACATCCTGCTTGCCTTC & \multirow{2}{*}{211} & \multirow{2}{*}{ Nawaz et al., 2006} & \multirow{2}{*}{53} \\
\hline & $\mathrm{R}$ & GCATAGATCGCCGTGAAGAG & & & \\
\hline \multirow{2}{*}{$\operatorname{tet}(\mathrm{M})$} & $\mathrm{F}$ & GTGGACAAAGGTACAACGAG & \multirow{2}{*}{406} & \multirow{2}{*}{$\mathrm{Ng}$ et al., 2001} & \multirow{2}{*}{55} \\
\hline & $\mathrm{R}$ & CGGTAAAGTTCGTCACACAC & & & \\
\hline
\end{tabular}


Table 4. Presence of tetracycline resistance genes in the wastewater treatment plant in the Region of Warmia and Mazury

\begin{tabular}{|c|c|c|c|c|}
\hline \multirow{2}{*}{ Symbol } & \multicolumn{4}{|c|}{ Prevalence of ARGs } \\
\cline { 2 - 5 } & \multicolumn{2}{|c|}{ tet(A) } & \multicolumn{2}{c|}{ tet(M) } \\
\cline { 2 - 5 } & June & November & June & November \\
\hline P1 & + & + & + & + \\
\hline P2 & + & + & + & + \\
\hline P3 & + & + & - & + \\
\hline P4 & + & + & + & + \\
\hline P5 & + & + & + & - \\
\hline P6 & + & + & - & - \\
\hline P7 & + & + & - & - \\
\hline P8 & + & + & + & - \\
\hline P9 & + & + & + & - \\
\hline
\end{tabular}

Table 5. Presence of tetracycline resistance genes in the wastewater treatment plant in the Region of Silesia

\begin{tabular}{|c|c|c|c|c|}
\hline \multirow{2}{*}{ Symbol } & \multicolumn{4}{|c|}{ Prevalence of ARGs } \\
\cline { 2 - 5 } & \multicolumn{2}{|c|}{ tet(A) } & \multicolumn{2}{c|}{ tet(M) } \\
\cline { 2 - 5 } & June & November & June & November \\
\hline P1 & + & + & + & + \\
\hline P2 & + & + & + & + \\
\hline P3 & + & + & + & + \\
\hline P4 & + & + & + & + \\
\hline P5 & + & + & + & + \\
\hline P6 & + & + & + & + \\
\hline P7 & + & + & + & + \\
\hline P8 & + & + & + & + \\
\hline P9 & + & + & + & + \\
\hline P10 & + & + & + & + \\
\hline
\end{tabular}

not effectively removed during the mechanical and biological wastewater treatment. This could pose a serious public health risk, which is why ARG levels should be regularly monitored in WWTPs and the environment.

\section{Acknowledgements}

Jakub Hubeny is a recipient of a scholarship from the Programme Interdisciplinary Doctoral Studies in Bioeconomy (POWR.03.02.00 $00 \mathrm{I} 034 / 16$ 00), which is funded by the European Social Funds. This study was supported by grants from the National Science Center (Poland): No. 2017/27/B/NZ9/00267 and No. 2017/26/M/NZ9/0007

\section{REFERENCES}

1. Boto L. 2014. Horizontal gene transfer in the acquisition of novel traits by metazoans. Proceedings of the Royal Society B: Biological Sciences, 281(1777), 20132450.

2. Chen G., Zhao L., \& Dong Y. H. 2011. Oxidative degradation kinetics and products of chlortetracycline by manganese dioxide. Journal of hazardous materials, 193, 128-138.

3. Chen H., \& Zhang M. 2013. Occurrence and removal of antibiotic resistance genes in municipal wastewater and rural domestic sewage treatment systems in eastern China. Environment international, 55, 9-14.

4. D'Costa V. M., King C. E., Kalan L., Morar M., Sung W. W., Schwarz C. \& Golding G. B. 2011. Antibiotic resistance is ancient. Nature, 477(7365), 457.

5. Daghrir R., \& Drogui P. 2013. Tetracycline antibiotics in the environment: a review. Environmental chemistry letters, 11(3), 209-227.

6. Deblonde T., Cossu-Leguille C., \& Hartemann P. 2011. Emerging pollutants in wastewater: a review of the literature. International journal of hygiene and environmental health, 214(6), 442-448.

7. Gao P., Munir M., \& Xagoraraki I. 2012. Correlation of tetracycline and sulfonamide antibiotics with corresponding resistance genes and resistant bacteria in a conventional municipal wastewater treatment plant. Science of the Total Environment, 421, 173-183.

8. Ghosh S., \& LaPara T. M. 2007. The effects of subtherapeutic antibiotic use in farm animals on the proliferation and persistence of antibiotic resistance among soil bacteria. The ISME journal, 1(3), 191.

9. Guo J., Li J., Chen H., Bond P. L., \& Yuan Z. 2017. Metagenomic analysis reveals wastewater treatment plants as hotspots of antibiotic resistance genes and mobile genetic elements. Water research, 123, 468-478.

10. Harnisz M., \& Korzeniewska E. 2018. The prevalence of multidrug-resistant Aeromonas spp. in the municipal wastewater system and their dissemination in the environment. Science of the Total Environment, 626, 377-383.

11. Harnisz M., Korzeniewska E., Ciesielski S., \& Gołaś I. 2015. tet genes as indicators of changes in the water environment: Relationships between culture-

12. He L. Y., Ying G. G., Liu Y. S., Su H. C., Chen J., Liu S. S., \& Zhao J. L. 2016. Discharge of swine wastes risks water quality and food safety: Antibiotics and antibiotic resistance genes from swine sources to the receiving environments. Environment international, 92, 210-219. dependent and culture-independent approaches. Science of the Total Environment, 505, 704-711. 
13. Jeong J., Song W., Cooper W. J., Jung J., \& Greaves J. 2010. Degradation of tetracycline antibiotics: mechanisms and kinetic studies for advanced oxidation/reduction processes. Chemosphere, 78(5), 533-540.

14. Korzeniewska E., Korzeniewska A., \& Harnisz M. 2013. Antibiotic resistant Escherichia coli in hospital and municipal sewage and their emission to the environment. Ecotoxicology and environmental safety, 91, 96-102.

15. Kümmerer K. 2009. Antibiotics in the aquatic environment-a review-part I. Chemosphere, 75(4), 417-434.

16. Laht M., Karkman A., Voolaid V., Ritz C., Tenson T., Virta M., \& Kisand V. 2014. Abundances of tetracycline, sulphonamide and beta-lactam antibiotic resistance genes in conventional wastewater treatment plants (WWTPs) with different waste load. PLoS One, 9(8), e103705.

17. Li R., Zhang Y., Lee C. C., Liu L., \& Huang Y. 2011. Hydrophilic interaction chromatography separation mechanisms of tetracyclines on amino-bonded silica column. Journal of separation science, 34(13), 1508-1516.

18. Michael I., Rizzo L., McArdell C. S., Manaia C. M., Merlin C., Schwartz T. \& Fatta-Kassinos D. 2013. Urban wastewater treatment plants as hotspots for the release of antibiotics in the environment: a review. Water research, 47(3), 957-995.

19. Moura A., Henriques I., Smalla K., \& Correia A. 2010. Wastewater bacterial communities bring together broad-host range plasmids, integrons and a wide diversity of uncharacterized gene cassettes. Research in microbiology, 161(1), 58-66.

20. Nawaz M., Sung K., Khan S. A., Khan A. A., \& Steele R. 2006. Biochemical and molecular characterization of tetracycline-resistant Aeromonas veronii isolates from catfish. Appl. Environ. Microbiol., 72(10), 6461-6466.

21. Ng L. K., Martin I., Alfa M., \& Mulvey M. 2001. Multiplex PCR for the detection of tetracycline resistant genes. Molecular and cellular probes, 15(4), 209-215.

22. Park C., \& Zhang J. 2012. High expression hampers horizontal gene transfer. Genome biology and evolution, 4(4), 523-532

23. Reijnders D., Goossens G. H., Hermes G. D., Neis E. P., van der Beek C. M., Most J., \& Groen A. K. (2016). Effects of gut microbiota manipulation by antibiotics on host metabolism in obese humans: a randomized double-blind placebo-controlled trial. Cell metabolism, 24(1), 63-74.
24. Rizzo L., Manaia C., Merlin C., Schwartz T., Dagot C., Ploy M. C., \& Fatta-Kassinos D. 2013. Urban wastewater treatment plants as hotspots for antibiotic resistant bacteria and genes spread into the environment: a review. Science of the total environment, 447, 345-360.

25. Schlüter A., Szczepanowski R., Pühler A., \& Top E. M. 2007. Genomics of IncP-1 antibiotic resistance plasmids isolated from wastewater treatment plants provides evidence for a widely accessible drug resistance gene pool. FEMS microbiology reviews, 31(4), 449-477.

26. Soucy S. M., Huang J., \& Gogarten J. P. 2015. Horizontal gene transfer: building the web of life. Nature Reviews Genetics, 16(8), 472.

27. von Wintersdorff,C. J., Penders J., van Niekerk J. M., Mills N. D., Majumder S., van Alphen L. B., \& Wolffs P. F. 2016. Dissemination of antimicrobial resistance in microbial ecosystems through horizontal gene transfer. Frontiers in microbiology, 7, 173.

28. World Health Organization. 2014. Antimicrobial resistance: global report on surveillance. World Health Organization. (ISBN: 9241564741).

29. Xiong W., Sun Y., Zhang T., Ding X., Li Y., Wang M., \& Zeng Z. 2015. Antibiotics, antibiotic resistance genes, and bacterial community composition in fresh water aquaculture environment in China. Microbial ecology, 70(2), 425-432.

30. Xu J., Xu Y., Wang H., Guo C., Qiu H., He Y. \& Meng W. 2015. Occurrence of antibiotics and antibiotic resistance genes in a sewage treatment plant and its effluent-receiving river. Chemosphere, 119, 1379-1385.

31. Zhang T., \& Li B. 2011. Occurrence, transformation, and fate of antibiotics in municipal wastewater treatment plants. Critical reviews in environmental science and technology, 41(11), 951-998.

32. Zhang X. X., \& Zhang T. 2011. Occurrence, abundance, and diversity of tetracycline resistance genes in 15 sewage treatment plants across China and other global locations. Environmental science \& technology, 45(7), 2598-2604.

33. Zhang X. X., Zhang T., \& Fang H. H. 2009. Antibiotic resistance genes in water environment. Applied microbiology and biotechnology, 82(3), 397-414.

34. Zhu Y. G., Johnson T. A., Su J. Q., Qiao M., Guo G. X., Stedtfeld R. D. \& Tiedje J. M. 2013. Diverse and abundant antibiotic resistance genes in Chinese swine farms. Proceedings of the National Academy of Sciences, 110(9), 3435-3440. 